\title{
Pengaruh Sarana Dan Prasarana Pendidikan Terhadap Kinerja Guru MTs. Negeri 4 Banyuwangi
}

\author{
Nur Hidayati ${ }^{1}$, Ufik Dzuroidah ${ }^{2}$ \\ e-mail: nurhidayati875@gmail.com¹,ufikdzuroidah14@gmail.com² \\ Prodi Manajemen Pendidikan Islam \\ Institut Agama Islam Darussalam Blokagung Banyuwangi
}

\begin{abstract}
This study aims to: (1) To find out about educational facilities and infrastructure in MTs 4 Banyuwangi Sumberberas Muncar Banyuwangi 2018/2019 Academic Year. (2) To find out the performance of teachers in MTs 4 Banyuwangi Sumberberas Muncar Banyuwangi 2018/2019 Academic Year. (3) To determine whether there is an influence of educational facilities and infrastructure on the performance of teachers in MTs 4 Banyuwangi Sumberberas Muncar Banyuwangi 2018/2019 Academic Year. (4) To find out how much influence educational facilities and infrastructure have on teacher performance in MTs 4 Banyuwangi Sumberberas Muncar Banyuwangi 2018/2019 Academic Year. In this study using quantitative descriptive methods with the product momunt technique in the validity test and using regression techniques for data analysis. The population of this study was 45 teachers of MTs Negeri 4 Banyuwangi Sumberberas Muncar Banyuwangi. After analyzing the data collected, it was found that (1) Means and Infrastructure of MTs 4 Banyuwangi Sumberberas Muncar Banyuwangi were very good. (2) Teacher performance in MTs Negeri 4 Banyuwangi Sumberberas Muncar Banyuwangi is very good. (3) There is an effect of the application of management functions on improving the quality of teaching staff of MTs Negeri 4 Banyuwangi Sumberberas Muncar Banyuwangi. (4) the influence of educational facilities and infrastructure on the performance of teachers in MTs Negeri 4 Banyuwangi Sumberberas Muncar Banyuwangi by $39 \%$.
\end{abstract}

Keywords: Facilities and Infrastructure, Teacher Performance

\begin{abstract}
Abstrak
Penelitian ini bertujuan untuk: (1) Untuk mengetahui tentang sarana dan prasarana pendidikan di MTs Negeri 4 Banyuwangi Sumberberas Muncar Banyuwangi Tahun Pembelajaran 2018/2019. (2) Untuk mengetahui kinerja guru di MTs Negeri 4 Banyuwangi Sumberberas Muncar Banyuwangi Tahun Pembelajaran 2018/2019. (3) Untuk mengetahui ada tidaknya pengaruh sarana dan prasarana pendidikan terhadap kinerja guru di MTs Negeri 4 Banyuwangi Sumberberas Muncar Banyuwangi Tahun Pembelajaran 2018/2019. (4) Untuk mengetahui seberapa besar pengaruh sarana dan prasarana pendidikan terhadap kinerja guru di MTs Negeri 4 Banyuwangi Sumberberas Muncar Banyuwangi Tahun Pembelajaran 2018/2019. Dalam penelitian ini menggunakan metode deskriptif kuantitatif dengan teknik product momunt pada uji validitas dan menggunakan teknik regresi untuk analisis data. Populasi penelitian ini adalah guru MTs Negeri 4 Banyuwangi Sumberberas Muncar Banyuwangi yang berjumlah 45. Setelah melakukan analisis data yang dikumpulkan, ditemukan bahwa (1) Sarana dan Prasarana Pendidika MTs Negeri 4 Banyuwangi Sumberberas Muncar Banyuwangi sangat baik. (2) Kinerja guru di MTs Negeri 4 Banyuwangi Sumberberas Muncar Banyuwangi sangat baik. (3) Ada pengaruh penerapan fungsi manajemen terhadap peningkatan mutu tenaga pendidik MTs Negeri 4 Banyuwangi Sumberberas Muncar Banyuwangi. (4) besar pengaruh sarana dan prasarana pendidikan terhadap kinerja guru MTs Negeri 4 Banyuwangi Sumberberas Muncar Banyuwangi sebesar 39\%.
\end{abstract}

Kata Kunci : Sarana dan Prasarana, Kinerja Guru 


\section{A. Pendahuluan}

\section{Latar Belakang}

Pendidikan merupakan suatu wadah yang sangat berperan penting bagi suatu negara, dalam mengembangkan serta membangun negara tersebut. Menurut Undang-Undang nomor 20 tahun 2003 tentang sistem pendidikan nasional menyatakan bahwa pendidikan merupakan usaha sadar dan terencana untuk mewujudkan suasana belajar dan proses pembelajaran agar peserta didik secara aktif mengembangkan potensi dirinya untuk memiliki kekuatan spiritual keagamaan, pengendalian diri, kepribadian, kecerdasan, akhlaq mulia, serta keterampilan yang diperlukan dirinya, masyarakat, bangsa dan Negara. Terkait dengan hal ini, pendidikan akan terus mengembangkan kualitas yang dimilikinya melalui pengelolaan yang efektif dan efisien terhadap sumber daya yang dimiliki baik bidang manusia ataupun materil. Kegiatan pendidikan yang memiliki sumber daya yang baik akan mencapai tingkat keberhasilan yang sangat tinggi.

Keberhasilan suatu lembaga pendidikan tersebut dipengaruhi dengan beberapa faktor antara lain guru, metode belajar dan mengajar, kurikulum, dan sarana prasarana pendidikan. Peningkatan keberhasilan pendidikan bukan hal yang sangat mudah namun sangatlah sulit dan rumit karena mencakup pengelolaan sistem lembaga pendidikan dan pengelolaan sistem pembelajaran. Sistem pembelajaran di sekolah merupakan tugas dan peran guru, yang mana guru mempunyai kuasa penuh terhadap jalan dan tidaknya suatu pembelajaran yang ada di kelas. Dari pernyataan di atas menunjukkan bahwa keadaan guru sangatlah berpengaruh dalam meningkatkan keberhasilan dari proses belajar mengajar.

Selain dari kegiatan pendidikan berupa proses pembelajaran yang dijalankan oleh seorang guru, dalam menunjang keberhasilan pendidikan baik secara langsung maupun tidak langsung diperlukan adanya fasilitas yang memadai sesuai dengan kebutuhan pendidikan sekolah. Fasilitas sekolah yang tak lain adalah sarana prasarana sekolah merupakan sumber daya materil yang wajib dimiliki oleh lembaga pendidikan guna untuk 
mencapai tujuan pendidikan. Hal ini sesuai dengan Undang-Undang Sistem Pendidikan Nasional No. 20 tahun 2003 Bab XII Pasal 45 tentang Sarana dan Prasarana Pendidikan menyatakan setiap satuan pendidikan formal dan nonformal menyediakan sarana dan prasarana yang memenuhi keperluan pendidikan sesuai dengan pertumbuhan dan perkembangan potensi fisik, kecerdasan intelektual, sosial, emosional, dan kejiwaan peserta didik.

Pihak sekolah yang bersangkutan harus memiliki tanggung jawab yang lebih atas sarana dan prasarana yang ada baik dalam masa perencanaan, pengadaan, penggunaan, penginventarisasi hingga penghapusan sarana prasarana yang digunakan. Lembaga pendidikan yang memiliki sarana prasarana yang sangat baik dan sesuai dengan kebutuhan akan memiliki nilai lebih dimana hal tersebut dapat menjadi tolak ukur keberhasilan pendidikan. Pendidikan yang baik dapat dilihat dari output atau lulusan yang dihasilkan. Untuk menghasilkan lulusan yang terbaik perlu adanya seorang pengajar atau guru yang memiliki kemampuan yang baik serta fasilitas yang memadai. Dari fasilitas tersebut memudahkan seorang guru untuk melaksanakan perannya sebagai seorang pendidik dan pengajar.

Seorang guru sebelum melaksanakan pembelajaran perlu adanya perangkat pembelajaran yang berupa silabus, RPP, prota, promes. Dalam pembuatan hal tersebut diperlukan adanya sarana yang memadai. Selain perangkat pembelajaran yang wajib dimiliki seorang guru, juga diperlukan tempat belajar yang nyaman bagi peserta didik belajar. Hal ini menunjukkan jika sarana dan prasarana juga sangat penting dalam proses belajar mengajar.

Pendidikan jenjang pertama merupakan awal dari keberhasilan pendidikan seorang peserta didik. Di mana masa tersebut peserta didik dituntut untuk menguasai materi lebih untuk jenjang berikutnya. Sehingga kualitas sekolah pada jenjang pertama akan membantu menjadi faktor dalam serta mendukung menunjang keberhasilan pendidikan berikutnya. 
Berdasarkan pengamatan yang telah dilakukan di MTs Negeri 4 Banyuwangi Sumberberas, yang mana sekolah ini berada pada lingkungan yang ramai dimana banyak sekolah-sekolah yang memberikan penawaran terhadap kualitas sekolah. Sehingga pihak sekolah melakukan peningkatan kualitas pendidikan melalui kinerja guru. Guru di MTs Negeri 4 Banyuwangi ini memiliki kineja yang baik hal ini dibuktikan dengan proses dalam pengelolaan kelas, pemberian materi belajar, serta dalam pemenuhan perangkat pembelajaran. Dalam hal ini seorang guru perlu adanya sarana dan prasarana yang menunjang dalam proses pembelajaran serta pembuatan perangkat pembelajaran. Sehingga dengan adanya proses pengelolaan sarana dan prasarana yang baik akan mendorong kegiatan belajar menjadi baik. Hal ini dilakukan dalam rangka untuk meningkatkan kualitas pendidikan MTs Negeri 4 Banyuwangi melalui kinerja guru.

2. Rumusan Masalah

1) Bagaimanakah sarana dan prasarana pendidikan di MTs Negeri 4 Banyuwangi?

2) Bagaimanakah kinerja guru di MTs Negeri 4 Banyuwangi?

3) Adakah pengaruh sarana dan prasarana pendidikan terhadap kinerja guru di MTs Negeri 4 Banyuwangi?

4) Seberapa besar pengaruh sarana dan prasarana pendidikan terhadap kinerja guru di MTs Negeri 4 Banyuwangi?

3. Tujuan Penelitian

1) Untuk mengetahui tentang sarana dan prasarana pendidikan di MTs Negeri 4 Banyuwangi.

2) Untuk mengetahui kinerja guru di MTs Negeri 4 Banyuwangi Sumberberas Muncar Banyuwangi.

3) Untuk mengetahui ada tidaknya pengaruh sarana dan prasarana pendidikan terhadap kinerja guru di MTs Negeri 4 Banyuwangi.

4) Untuk mengetahui seberapa besar pengaruh sarana dan prasarana pendidikan terhadap kinerja guru di MTs Negeri 4 Banyuwangi.

4. Manfaat Penelitian

1) Secara teoritis 
a. Penelitian ini diharapkan dapat menambah pengetahuan terkait sarana dan prasarana pendidikan terhadap kinerja guru yang terdapat pada sekolah.

b. Sebagai bahan informasi dan referensi bagi peneliti yang ingin melakukan penelitian terkait sarana dan prasarana pendidikan maupun kinerja guru.

2) Secara praktis

a. Lembaga Sekolah

Memberikan solusi terhadap adanya sarana dan prasarana di MTs Negeri 4 Banyuwangi agar lebih baik dan relevan dengan perkembangan zaman, sehingga kinerja gurunya sesuai dengan yang diharapkan oleh stakeholder.

b. Masyarakat

Memberikan gambaran mengenai sekolah dengan pengelolaan sarana dan prasarana yang baik dalam menunjang aktifitas pembelajaran oleh guru menjadi efektif dan efisien untuk menghasilkan lulusan (output) yang terbaik.

\section{B. Landasan Teori}

a. Landasan teori sarana dan prasarana

1) Pengertian sarana dan prasarana

Dalam hal ini Barnawi \& Arifin (2016:47) menyatakan mengenai sarana adalah serangkai peralatan, bahan, dan perabot yang secara langsung digunakan dalam proses pendidikan yang ada di sekolah. Selain itu juga menyatakan mengenai sesuatu yang berkaitan dengan sarana pendidikan yakni prasarana. Prasarana pendidikan yaitu seluruh peragkat atau serangkaian perlengkapan dasar yang secara tidak langsung digunakan dalam menunjang pelaksanaan proses pendidikan di sekolah.

Menurut farikhah (2015:82) juga menyatakan mengenai sarana dan prasarana pendidikan. Sarana pendidikan merupakan peralatan atau perlengkapan yang secara langsung digunakan dan menunjang proses pendidikan khususnya pembelajaran misalnya papan tulis, 
spidol, penghapus, alat tulis, dan lain sebagainya. Sedangkan prasarana pendidikan adalah fasilitas yang secara tidak langsung digunakan dalam menunjang proses pembelajaran pada suatu lembaga pendidikan seperti gedung sekolah, ruang kelas, halaman, kebun sekolah, dan jalan menuju sekolah.

Pendapat lain yang juga menyatakan mengenai sarana dan prasarana pendidikan disampaikan oleh Martin \& Fuad (2018:1) bahwa sarana dan prasaran pendidikan merupakan salah satu pokok penting atau sumber daya yang sangat penting dalam menunjang keberhasilan proses pembelajaran yang ada disekolah.

Jadi dari beberapa pendapat yang dikemukakan oleh para ahli diatas dapat disimpulkan bahwa sarana dan prasaran pendidikan adalah suatu komponen penting yang langsung maupun tidak langsung digunakan dalam melakukan proses pendidikan untuk mencapai tujuan pendidikan yang efektif dan efisien.

2) Klasifikasi sarana dan prasarana

Klasifikasi dalam sarana pendidikan dibagi atas tiga golongan yakni berdasarkan habis dan tidaknya, berdasarkan bergerak tidaknya, serta berdasarkan hubungan dalam pembelajaran. Selain klasifikasi sarana juga ada penggolongan mengenai prasarana yakni digolongkan kedalam dua macam yakni langsung dan tidak langsung. Prasarana langsung misalnya dalam proses pembelajaran meliputi ruang kelas, laboratorium, ruang praktek, dan ruang komputer. Sedangkan sarana tidak langsung meliputi kantin, ruang kantor, kamar kecil, UKS, taman, dan tempat parkir.

3) Proses pendayagunaan dan pengadaan sarana dan prasarana

Adapun proses atau upaya pendayagunaan dan pengadaan saran dan prasarana menurut Indrawan (2015:9) sesuai siklus sebagai berikut:
a) Perencanaan
b) Pengadaan
c) Pengaturan 
d) Penggunaan

e) Penghapusan

4) Ayat Al Qur'an Tentang Sarana dan Prasarana Pendidikan

Sarana dan prasarana pendidikan merupakan suatu komponen yang wajib ada dalam suatu lembaga pendidikan. Karena dengan adanya sarana dan prasarana pendidikan yang baik dan mendukung seluruh kegiatan belajar mengajar, serta kegiatan lain yang berkaitan pendidikan akan menjadikan keberhasilan yang tinggi bagi suatu lembaga pendidikan. Pentingnya sarana dan prasarana pendidikan juga telah diterangkan Allah SAW dalam Al Qur'an QS An Nahl Ayat 69:

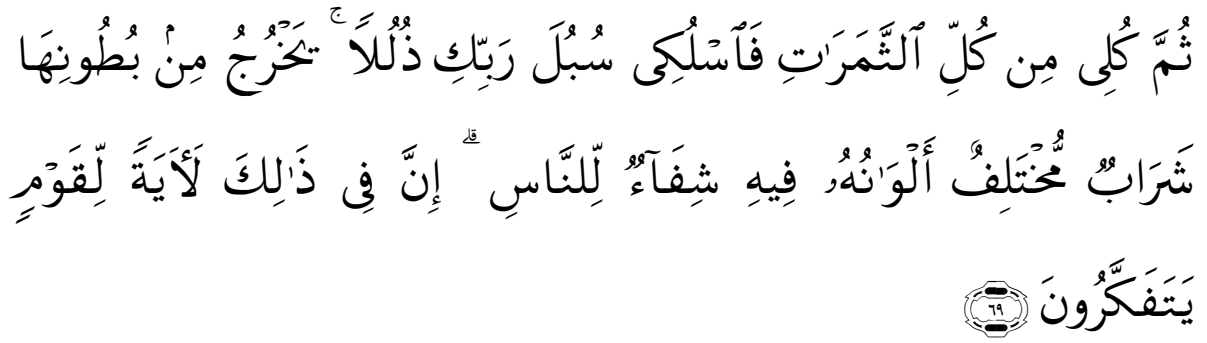

Artinya: kemudian makanlah dari tiap-tiap (macam) buah-buahan dan tempuhlah jalan Tuhanmu yang telah dimudahkan (bagimu). dari perut lebah itu ke luar minuman (madu) yang bermacam-macam warnanya, di dalamnya terdapat obat yang menyembuhkan bagi manusia. Sesungguhnya pada yang demikian itu benar-benar terdapat tanda (kebesaran Tuhan) bagi orang-orang yang memikirkan.

Ayat di atas menerangkan bahwa lebah bisa menjadi media atau alat bagi orang-orang yang berpikir untuk mengenal kebesaran Allah yang pada gilirannya akan meningkatkan keimanan dan kedekatan (taqarrub) seorang hamba kepada Allah Swt. Nabi Muhammad saw. dalam mendidik para sahabatnya juga selalu menggunakan alat atau media, baik berupa benda maupun non-benda.

b. Landasan Teori Tentang Kinerja Guru

1) Pengertian kinerja guru

Dalam melakukan suatu pekerjaan setiap individu diharapkan mampu melakukan tugas dan kepercayaan yang diberikan kepadanya dengan baik serta mampu memberikan konstribusi yang sangat 
memuaskan untuk mencapai tujuan dari suatu organisasi. Kinerja guru merupakan suatu hal yang sangat penting untuk menunjang keberhasilan pendidikan. Dalam hal ini kinerja guru memiliki definisi yang banyak mengingat kinerja guru berasal dari dua suku kata yakni kinerja dan guru.

Menurut Mangkunegara (2009:67) istilah kinerja berasal dari bahasa inggis yakni Job Performance atau Actual Performance ( prestasi kerja atau prestasi sesungguhnya yang dicapai oleh seseorang dalam pekerjaannya baik secara kuantitas maupun kualitas dalam menjalankan tugasnya sesuai dengan tanggung jawab yang diberikan kepadanya.

Pendapat lain dari Pianda (2018:11) mengatakan kinerja adalah kata yang memiliki dasar "kerja" dalam Bahasa Indonesia yaitu suatu jawaban mengenai berhasil atau tidaknya suatu organisasi atau lembaga pendidikan dengan tujuan yang telah ditetapkan. Atau juga dengan kata lain bahwa kinerja adalah suatu hasil atau taraf kesuksesan yang telah dicapai oleh pekerja atas apa yang telah dikerjakannya. Hal ini sejalan dengan yang dikemukakan Sagala (2010:180) bahwasanya kinerja merupakan suatu perilaku yang menunjukan efektifitas dan efisiensi seseorang dalam mencapai hasil karya dalam tugasnya.

Dari definisi kinerja para pakar diatas dapat disimpulkan bahwa kinerja merupakan suatu tinggat keberhasilan yang telah dicapai oleh seseorang dengan menunjukkan perilaku efektif dan efisien untuk mencapai tujuan suatu organisasi.

Selain dari definisi mengenai kinerja juga diperlukan mengenai definisi guru. Tak ada seorang pun yang tidak mengenal tentang sosok guru. Menurut pianda (2018:13) menyatakan guru adalah sosok pendidik profesional yang mana bertugas utama untuk mendidik, mengajar, mengarahkan, melatih, dan mengevaluasi peserta didik. 
Figur guru adalah figur yang mana mereka sangat berperaan dalam membantu perkembangan peseeta didik dalam mencapai tujuan hidupnya secara optimal.

Menurut Ki Hajar Dewantara menyebut sosok guru sebagai tut wuri handayani, ing madyo mangun karsa, ing ngarso mung tulodho. Menurut Yamin \& Maisah (2006:106) menyatakah bahwa guru adalah salah satu komponen penting yang berpengaruh dan memliki peran penting serta seorang guru juga merupakan kunci pokok bagi keberhasilan peningkatan mutu pendidikan.

Dari berbagai pendapat ahli mengenai kinerja dan guru diatas dapat di simpulkan bahwa kinerja guru merupakan suatu perbuatan atau kemampuan yang dilakukan oleh seseorang guru yang menghasilkan karya kerja dari tanggung jawabnya dengan kesesuaian terhadap tujuan sekolah.

2) Faktor Yang Mempengaruhi Kinerja Guru

Seorang guru merupakan ujung tombak dari keberhasilan seorang peserta didik, yang mana keberadaan guru dalam melaksanakan tugas dan perannya dapat mencerminkan ketercapaian dari tujuan pendidikan. Menurut Mangkunegara (2009:67) faktor yang mempengaruhi kinerja guru adalah dari faktor kemampuan (ability) dan faktor motivasi (motivation).

a) Faktor Kemampuan

Kemampuan seorang guru sangatlah diperlukan dalam menjalankan seluruh perannya. secara psikolagis kemampuan seseorang terhadap pekerjaannya terdiri kemampuan IQ (potensi) dan kemampuan reality (knowladge+skill). Artinya seorang guru yang memiliki pendidikan yang tinggi dan sesuai dengan bidangnya akan mempermudah seorang guru dalam mencapai hasil kerja yang ingin dicapai. Seorang guru yang menempati sesuai dengan bidangnya akan membantu dalam keefektifan suatu pembelajaran. 
b) Faktor Motivasi

Motivasi terbentuk dari sikap seorang guru dalam menghadapi situasi kerjanya.motivasi merupakan suatu kondisi dimana dalam kondisi tersebut yang menggerakkan seorang guru menjadi terarah untuk mencapai tujuan pendidikan. menurut Davit dalam Mangkunegara (2009:68) mengemukakan bahwa ada hubungan yang positif antara motif berprestasi dengan pencapaian kinerja. motif berprestasi adalah dorongan dari diri seorang guru untuk melakukan tugasnya dengan sebaik-baiknya agar mampu mencapai kinerja yang terbaik.

Dalam hal ini ada 6 karakteristik yang mendasari seorang guru memiliki motif berprestasi antara lain:

a) Tanggung jawab pribadi yang tinggi

b) Berani mengambil resiko

c) Memiliki tujuan yang realitis

d) Memiliki rencana kerja yang menyeluruh dan berjuang untuk merealisasikannya

e) Memanfaatkan umpan balik (feedback)

f) Mencari kesempatan untuk merealisasikan programnya

3) Ayat Al Qur'an Tentang kinerja guru

Dalam suatu lembaga pendidkan peran dari seorang guru sagatlah penting. Karena kinerja dari seorang guru merupakan pusat dari selruh keberhasilan yang akan dicapai oleh peserta didik. Dalam hal tersebut pada Al Qur'an QS Huud ayat 61 juga menjelaskan bagaimana pentingnya dari adanya suatu kinerja yang baik yang berbunyi:

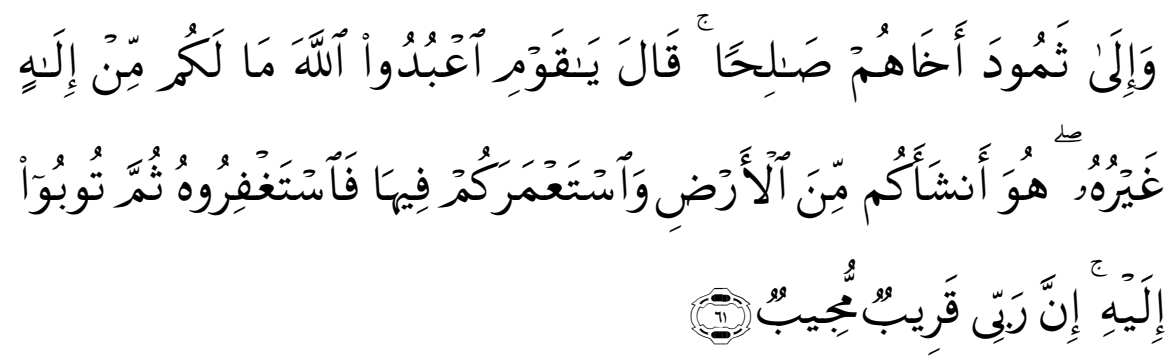

Artinya: dan kepada Tsamud (kami utus) saudara mereka shaleh. Shaleh berkata: "Hai kaumku, sembahlah Allah, sekali- 
kali tidak ada bagimu Tuhan selain Dia. Dia telah menciptakan kamu dari bumi (tanah) dan menjadikan kamu pemakmurnya[726], karena itu mohonlah ampunanNya, kemudian bertobatlah kepada-Nya, Sesungguhnya Tuhanku Amat dekat (rahmat-Nya) lagi memperkenankan (doa hamba-Nya)."

Dari ayat tersebut diterangkan bahwasannya manusia dijadikan seorang penguasa dan memakmurkan dunia/bumi. Sehingga manusia harus melakukan seluruh kemampuannya untuk bekerja dengan keras yang nantinya akan mewujudkan hasil yang lebih baik dan terus meningkat.dalam hal ini yang bekerja adalah seorang guru atau pendidik yang mana seorang pendidik harus memberikan seluruh kemampuan/kinerja yang ia miliki untuk mewujudkan hasil atau tujuan yang telah ditentukan. Jadi dapat disimpulkan jika dengan adanya hasil/tujuan sekolah/madrasah yang terus meningkat, maka sekolah pun akan menjadi lebik baik dari sebelumnya.

c. Penelitian terdahulu

1)Penelitian oleh Maria Ulfa yang berjudul Implementasi Sarana dan Prasarana dalam Meningkatkan Kualitas Pendidikan di Madrasah Aliyah Negeri Malang. Penelitian ini menggunakan teknik penelitian kualitatif deskriftif. Penelitian ini menggunakan teknik pengumpulan data dengan observasi, wawancara, dan dokumentasi. Dari penelitian tersebut menghasilkan kelengkapan dari sarana prasarana sangat mempengaruhi terhadap kualitas pendidikan yang mana dengan adanya sarana dan prasarana yang baik akan memudahkan proses belajar mengajar.

2)Penelitian oleh Safitri Lucky Martati yang berjudul Implementasi Pengellolaan Sarana Dan Prasrana Dalam Meningkatkan Mutu Pendidikan di Smk Full Day Sunan Ampel Bangorejo Banyuwangi Tahun Pelajaran 2017/2018. Penelitian ini menggunakan teknik kualitatif deskriptif. Penelitian ini menggunakan teknik pengumpulan data dengan observasi, wawancara, dan dokumentasi. Dari penelitian tersebut menghasilkan kegiatan dalam meningkatkan mutu pendidikan 
diperlukan adanya pengelolaan sarana dan prasarana yang meliputi perencanaan, pengadaan, pemeliharaan, dan pengawasan.

3)Penelitian oleh Umar Umayah yang berjudul Strategi Dan Keterampilan Kepala Madrasah Dalam Meningkatkan Kinerja Guru Di Mts Unggulan Mukhtar Syafaat Blokagung Tegalsari Banyuwangi. Penelitian ini menggunakan teknik penelitian kualitatif deskriftif. Penelitian ini menggunakan teknik pengumpulan data dengan observasi, wawancara, dan dokumentasi. Dari penelitian tersebut menghasilkan pelaksanaan strategi kepala sekolah terhadap kinerja guru sudah berjalan dengan baik namun belum berjalan secara maksimal.

Adapun dari penelitian diatas memunculkan adanya perbedaan dan persamaan. Persamaan yang terjadi dari penelitian diatas dengan penelitian yang dilakukan peneliti terletak pada pembahasaan atau tema. Yang mana pada penelitian pertama dan kedua membahas mengenai sarana dan prasarana pendidikan dan pada penelitian yang ketiga membahas tentang kinerja guru. Adapun perbedaannya adalah peneliti menggunakan metode kuantitatif dan menghubungkan tentang sarana dan prasarana terhadap kinerja guru.

\section{Metode Penelitian}

1. Jenis Penelitian ini deskriptif kuantitatif

2. Populasi yang digunakan dalam penelitian ini bersifat penelitian populasi karena jumlah subjek kurang dari 100

3. Teknik Pengumpulan Data yang digunakan adalah observasi, wawancara, angket dan dokumentasi

4. Validitas data menggunakan rumus korelasi product moment

5. Reliabilitas data menggunakan rumus Alpha

6. Uji normalitas data menggunakan rumus Kolmogorof Smirnov

7. Analisis data menggunakan rumus regresi linier sederha 


\section{Hasil Penelitian}

1. Uji Validitas

Uji validitas merupakan cara untuk menguji apakah instrumen yang digunakan dapat mengukur apa yang seharusnya diukur atau tidak. Dalam hal ini dilakukan dengan t-test yaitu membandingkan antara $r$ hitung dan $r$ tabel. Apabila $\mathrm{r}$ hitung lebih besar dari t tabel maka perbedaan yang ada adalah signifikan, sehingga instrumen bisa dikatakan valid. Tingkat signifikansi pada uji r adalah 0,05 atau $5 \%$.

Tabel 1

Hasil Uji Validitas Data

\begin{tabular}{|c|c|c|c|c|}
\hline no & Item & Corrected item- & $r$ tabel & Kriteria \\
\hline 1 & $\mathrm{X} 1$ & 0,688 & $>0,301$ & Valid \\
\hline 2 & $\mathrm{X} 2$ & 0,649 & $>0,301$ & Valid \\
\hline 3 & $\mathrm{X} 3$ & 0,649 & $>0,301$ & Valid \\
\hline 4 & $\mathrm{X} 4$ & 0,790 & $>0,301$ & Valid \\
\hline 5 & $\mathrm{X} 5$ & 0,814 & $>0,301$ & Valid \\
\hline 6 & $\mathrm{X} 6$ & 0,534 & $>0,301$ & Valid \\
\hline 7 & $\mathrm{X} 7$ & 0,674 & $>0,301$ & Valid \\
\hline 8 & $\mathrm{X} 8$ & 0,668 & $>0,301$ & Valid \\
\hline 9 & $\mathrm{X} 9$ & 0,628 & $>0,301$ & Valid \\
\hline 10 & X10 & 0,719 & $>0,301$ & Valid \\
\hline 11 & $\mathrm{X} 11$ & 0,556 & $>0,301$ & Valid \\
\hline 12 & $\mathrm{X} 12$ & 0,815 & $>0,301$ & Valid \\
\hline 13 & $\mathrm{X} 13$ & 0,463 & $>0,301$ & Valid \\
\hline 14 & X14 & 0,707 & $>0,301$ & Valid \\
\hline 15 & $\mathrm{X} 15$ & 0,626 & $>0,301$ & Valid \\
\hline 16 & Y1 & 0,698 & $>0,301$ & Valid \\
\hline 17 & $\mathrm{Y} 2$ & 0,688 & $>0,301$ & Valid \\
\hline 18 & $\mathrm{Y} 3$ & 0,610 & $>0,301$ & Valid \\
\hline 19 & $\mathrm{Y} 4$ & 0,681 & $>0,301$ & Valid \\
\hline 20 & Y5 & 0,545 & $>0,301$ & Valid \\
\hline 21 & Y6 & 0,612 & $>0,301$ & Valid \\
\hline 22 & Y7 & 0,614 & $>0,301$ & Valid \\
\hline 23 & $\bar{Y} 8$ & 0,685 & $>0,301$ & Valid \\
\hline 24 & Y9 & 0,614 & $>0,301$ & Valid \\
\hline 25 & Y10 & 0,807 & $>0,301$ & Valid \\
\hline 26 & Y11 & 0,538 & $>0,301$ & Valid \\
\hline 27 & Y12 & 0,824 & $>0,301$ & Valid \\
\hline 28 & Y13 & 0,552 & $>0,301$ & Valid \\
\hline 29 & Y14 & 0,583 & $>0,301$ & Valid \\
\hline 30 & Y15 & 0,550 & $>0,301$ & Valid \\
\hline
\end{tabular}

Sumber data: olahan peneliti 
Berdasarkan data diatas diketahui bahwa semua pengujian terhadap instrumen variabel $\mathrm{X}$ dan $\mathrm{Y}$ menunjukkan bahwa seluruh pertanyaan yang diajukan valid. Nilai $\mathrm{r}$ tabel untuk taraf signifikansi 0,05 atau $5 \%$ dan $\mathrm{dk}$ 45-2=43 adalah 0,301 dengan demikian semua pernyataan dalam kuesioner dapat dipercaya dan dapat digunakan untuk mengumpulkan data yang diperlukan.

2. Uji Reliabilitas

Suatu instrumen dikatakan reliabel apabila instrumen tersebut digunakan untuk mengukur gejala atau objek yang sama dari satu kali akan diperoleh hasil yang sama atau konstan. Pengujian reliabilitas dilakukan dengan menggunakan teknik Cronbach Alpha sehingga data dapat dikatakan reliabel jika nilai data variabel > 0,6.

Tabel 2

Hasil Uji Reliabilitas Data

\begin{tabular}{|c|l|c|l|}
\hline No & \multicolumn{1}{|c|}{ Variabel } & Cronbach Alpha & \multicolumn{1}{|c|}{ Kriteria } \\
\hline 1 & $\begin{array}{l}\text { Sarana Dan Prasarana } \\
\text { Pendidikan }\end{array}$ & 0,896 & Sangat Kuat \\
\hline 2 & Kinerja Guru & 0,766 & Kuat \\
\hline
\end{tabular}

Sumber data: olahan peneliti.

Hasil analisis dari tabel di atas menunjukkan bahwa nilai Cronbach Alpha dari masing-masing variabel terdapat pada kriteria kuat. Sehingga dapat disimpulkan bahwa semua alat ukur yang digunakan dalam penelitian ini adalah reliabel.

3. Uji Asumsi Klasik (Uji Normalitas Data)

Uji normalitas merupakan cara untuk menguji apakah variabelvariabel dalam sebuah model regresi mempunyai distribusi normal atau tidak. Pengujian dilakukan dengan menggunakan Kolmogorov semirnov, yaitu dengan melihat bagaimana penyebran titik pada sumbu diagonal. Pengujian normalitas data menunjukkan model sebaran data sebagai berikut: 
Tabel 3

Hasil Uji Normalitas

One-Sample Kolmogorov-Smirnov Test

\begin{tabular}{|c|c|c|c|}
\hline & & $\begin{array}{c}\text { sarana dan } \\
\text { prasarana }(x)\end{array}$ & kinerja guru $(y)$ \\
\hline $\mathrm{N}$ & & 45 & 45 \\
\hline Normal Parameters ${ }^{\mathrm{a}}$ & Mean & 69.5111 & 68.6444 \\
\hline & Std. Deviation & 4.96635 & 5.30075 \\
\hline Most Extreme Differences & Absolute & .218 & .161 \\
\hline & Positive & .135 & .115 \\
\hline & Negative & -.218 & -.161 \\
\hline Kolmogorov-Smirnov Z & & 1.461 & 1.077 \\
\hline Asymp. Sig. (2-tailed) & & .028 & .197 \\
\hline a. Test distribution is Norm & & & \\
\hline
\end{tabular}

Sumber data: SPSS 23

Normal P-P Plot of Regression Standardized Residual

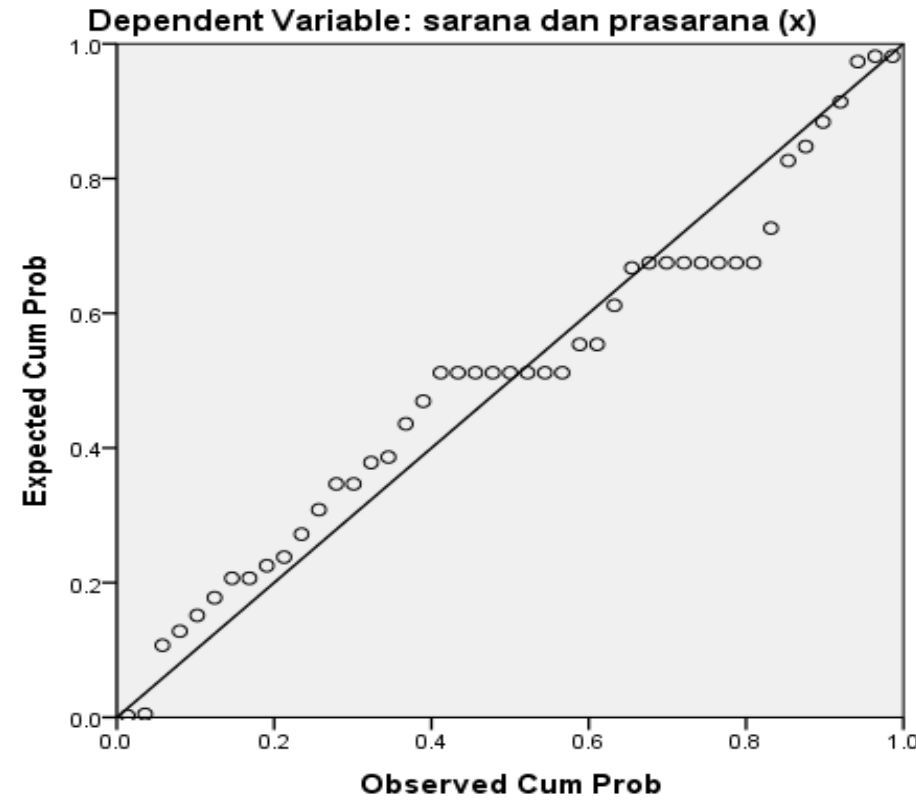

Gambar 4.2 Sebaran Data Uji Normalitas

Dari plot di atas dapat disimpulkan bahwa:

1) Variabel-Variabel tersebut mempunyai hubungan yang cukup dekat, karena titik-titik pada diagram pencar itu terletak mendekat pada garis.

2) Variabel-variabel tersebut mempunyai hubungan positif karena titik-titik pada diagram pencar menunjukan gejala dari bawah ke kanan atas.

Pengaruh Sarana Dan Prasarana Pendidikan Terhadap Kinerja Guru MTS

Negeri 4 Banyuwangi

Nur Hidayati, Ufik Dzuroidah 
3) Variabel-variabel tersebut mempunyai korelasi yang linier, karena titik-titik pada diagram pencar menunjukkan gejala garis lurus.

4) Sebaran data ada di sekitar garis diagonal sehingga dapat diambil kesimpulan bahwa data berdistribusi normal.

4. Analisis Data dan Pengujian Hipotesis

Sebagaimana disampaikan pada bagian sebelumnya bahwa penelitian ini menggunakan 1 variabel bebas atau 1 prediktor. Untuk keperluan analisis akan digunakan teknik regresi linier sederhana dengan rumus sebagai berikut : $Y=a+b X$

Berikut ini akan disajikan hasil analisis regresinya.

Tabel 4

Hasil Analisis Regresi

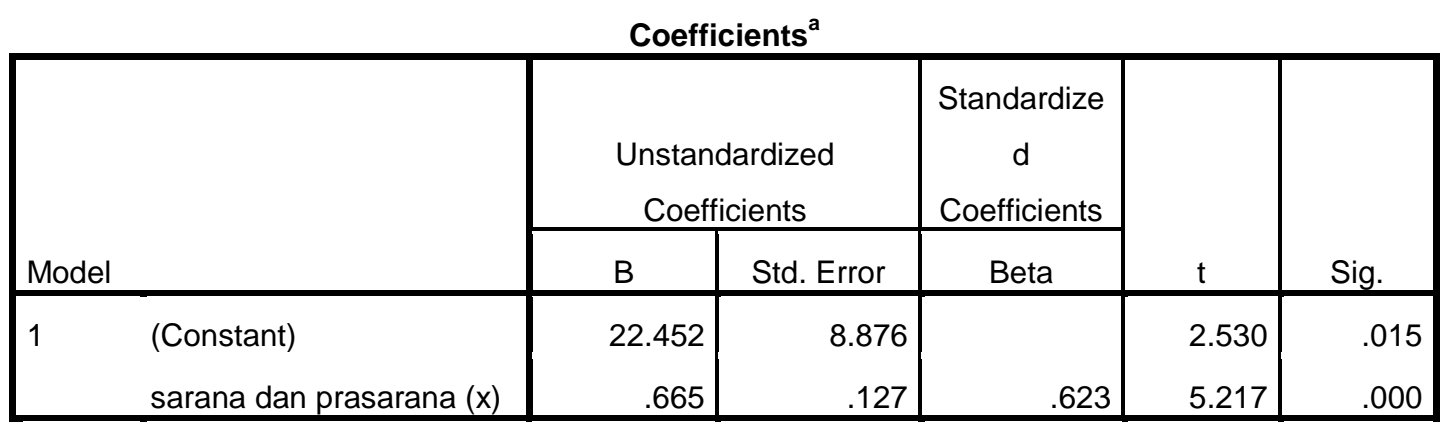

a. Dependent Variable: kinerja guru $(\mathrm{y})$

Sumber data: SPSS 23

Berdasarkan hasil yang tersaji tabel tersebut diperoleh regresinya yaitu:

$$
Y=22,452+0,665 X
$$

a) Pengujian hipotesis

Analisis regresi memerlukan pengujian yang sesuai untuk memastikan keeratan hubungan dari variabel-variabel yang digunakan. Pengujian tersebut meliputi uji F dan T.

a. Uji T

Uji T digunakan untuk mengetahui apakah pengaruh variabel sarana dan prasarana (X) dan variabel kinerja guru (Y) signifikan atau tidak. Kesimpulan dari uji $\mathrm{T}$ diperoleh setelah 
membandingkan $t$ hitung dan $t$ tabel dengan taraf signifikansi 0,05 atau 5\%. Kriteria pengambilan keputusannya adalah:

1) Apabila t hitung $>\mathrm{t}$ tabel, maka Ho ditolak dan Ha diterima, yang artinya variabel bebas secara parsial memiliki pengaruh nyata dan signifikan terhadap variabel terikat.

2) Apabila t hitung < t tabel, maka Ho diterima dan Ha ditolak, yang artinya variabel bebas secara parsial tidak memiliki pengaruh nyata dan tidak signifikan terhadap variabel terikat.

Hasil analisis uji t dalam penelitian ini disajikan dalam tabel berikut:

Tabel 5

Hasil Uji T

\begin{tabular}{|c|c|c|c|c|c|c|}
\hline \multicolumn{7}{|c|}{ Coefficients $^{a}$} \\
\hline \multirow{2}{*}{\multicolumn{2}{|c|}{ Model }} & \multicolumn{2}{|c|}{ Unstandardized Coefficients } & \multirow{2}{*}{\begin{tabular}{|c|} 
Standardized \\
Coefficients \\
Beta \\
\end{tabular}} & \multirow[b]{2}{*}{$\mathrm{T}$} & \multirow[b]{2}{*}{ Sig. } \\
\hline & & $\mathrm{B}$ & Std. Error & & & \\
\hline 1 & $\begin{array}{l}\text { (Constant) } \\
\text { sarana dan prasarana } \\
\text { (x) }\end{array}$ & $\begin{array}{r}22.452 \\
.665\end{array}$ & $\begin{array}{r}8.876 \\
.127\end{array}$ & .623 & 2.530 & .015 \\
\hline
\end{tabular}

a. Dependent Variable: kinerja guru $(\mathrm{y})$

Sumber data: SPSS 23

Berdasarkan tabel hasil analisis uji t tersebut dapat ditarik kesimpulan bahwa thitung > t tabel, yaitu $5.217>2,021$, maka Ho ditolak dan Ha diterima. Hal tersebut berarti bahwa variabel sarana dan prasarana $(\mathrm{X})$ mempunyai pengaruh yang signifikan terhadap kinerja guru (Y).

b. Uji F

Uji F atau uji koefisien regresi secara serentak digunakan untuk mengetahui apakah variabel sarana dan prasarana $(\mathrm{X})$ dan variabel kinerja guru (Y) secara signifikan atau tidak. Kesimpulan dari uji F ini diperoleh dengan cara membandingkan antara $\mathrm{F}$ hitung dan $\mathrm{F}$ tabel dengan taraf signifikansi 0,05. Kriteria pengambilan keputusannya adalah: 
1) Apabila $F$ hitung > F tabel, maka Ho ditolak dan Ha diterima, yang artinya variabel bebas secara simultan memiliki pengaruh yang signifikan terhadap variabel terikat.

2) Apabila F hitung < F tabel, maka Ho diterima dan Ha ditolak, yang artinya variabel bebas secara simultan tidak memiliki pengaruh yang signifikan terhadap variabel terikat.

Hasil analisis uji $\mathrm{F}$ dalam penelitian ini disajikan dalam tabel berikut ini:

Tabel 6

Hasil Uji F

\begin{tabular}{|ll|r|r|r|c|c|}
\hline \multicolumn{7}{|c|}{ ANOVA $^{\mathrm{b}}$} \\
\hline Model & & Sum of Squares & Df & Mean Square & F & \multicolumn{1}{c|}{ Sig. } \\
\hline 1 & Regression & 479.244 & 1 & 479.244 & 27.220 & $.000^{\mathrm{a}}$ \\
& Residual & 757.067 & 43 & 17.606 & & \\
& Total & 1236.311 & 44 & & & \\
\hline
\end{tabular}

a. Predictors: (Constant), sarana dan prasarana $(\mathrm{x})$

b. Dependent Variable: kinerja guru $(y)$

Sumber data: SPSS 23

Berdasarkan hasil yang tersaji pada tabel tersebut di atas diketahui bahwa $\mathrm{F}$ hitung $>\mathrm{F}$ tabel $(27,220>1,66)$ sehingga Ho ditolak dan Ha diterima, yang berarti variabel bebas, yaitu sarana dan prasarana $(\mathrm{X})$ dan kinerja guru (Y) secara simultan atau bersama-sama memiliki pengaruh signifikan terhadap variabel terikat motivasi belajar (Y).

Sedangkan untuk mengetahui tentang besarnya pengaruh dari seluruh variabel independen $(\mathrm{X})$ terhadap variabel dependent (Y) menggunakan output regresi model summary berikut ini:

Tabel 7

Model Summary

Model Summary ${ }^{b}$

\begin{tabular}{|l|c|r|r|r|r|}
\hline Model & R & R Square & $\begin{array}{c}\text { Adjusted R } \\
\text { Square }\end{array}$ & $\begin{array}{c}\text { Std. Error of } \\
\text { the Estimate }\end{array}$ & $\begin{array}{c}\text { Durbin- } \\
\text { Watson }\end{array}$ \\
\hline 1 & $.623^{\mathrm{a}}$ & .388 & .373 & 4.19597 & 1.451 \\
\hline
\end{tabular}

Sumber data: SPSS 23

Pengaruh Sarana Dan Prasarana Pendidikan Terhadap Kinerja Guru MTS

Negeri 4 Banyuwangi

Nur Hidayati, Ufik Dzuroidah 
Berdasarakan hasil yang disajikan pada tabel diatas diketahui bahwa nilai $\mathrm{R}$ atau koefisien korelasi sebesar 0,623, sedangkan R Squre, hasil pengkuadratan nilai $\mathrm{R}$ atau koefisien determinansi (KD) sebesar 0,388, yang diartikan bahwa variabel bebas $\mathrm{X}$ memiliki pengaruh konstribusi sebesar 38,8\% yang dibulatkan menjadi 39\% terhadap variabel Y dan $61 \%$ dipengaruhi oleh faktor-faktor lain diluar variabel X.

\section{E. Pembahasan}

1. Pengaruh Sarana dan Prasarana (X)

Sesuai dengan apa yang diuraikan pada bagian sebelumnya bahwa permasalahan pertama yang dipertanyakan dalam penelitian ini adalah bagaimana sarana dan prasarana pendidikan MTs Negeri 4 Banyuwangi Tahun Pembelajaran 2018/2019, Hasil penelitian ini menunjukkan bahwa tingkat prosentase variabel $\mathrm{X}$ yang berhasil dicapai adalah sebagai berikut:

$$
\begin{aligned}
\% & =\frac{n}{N} \times 100 \\
& =\frac{3128}{3375} \times 100 \% \\
& =93 \%
\end{aligned}
$$

Berdasarkan data di atas, tingkat prosentase variabel $\mathrm{X}$ yang berhasil dicapai adalah sebesar 93\%. Jika dilihat pada tabel indeks konfirmasi nilai angket, maka nilai tersebut berada pada interval $81 \%$ sampai dengan $100 \%$ dengan kategori sangat kuat. Dengan demikian menunjukkan bahwa penerapan sarana dan prasarana MTs Negeri 4 Banyuwangi tergolong sangat baik.

2. Kinerja guru $(\mathrm{Y})$

Sesuai dengan apa yang diuraikan pada bagian sebelumnya bahwa permasalahan pertama yang dipertanyakan dalam penelitian ini adalah bagaimana kinerja guru MTs Negeri 4 Banyuwangi Tahun Pembelajaran 2018/2019, Hasil penelitian ini menunjukkan bahwa tingkat prosentase variabel Y yang berhasil dicapai adalah sebagai berikut:

$$
\%=\frac{n}{N} x 100
$$

Pengaruh Sarana Dan Prasarana Pendidikan Terhadap Kinerja Guru MTS 


$$
\begin{aligned}
& =\frac{3089}{3375} \times 100 \% \\
& =92
\end{aligned}
$$

Berdasarkan data di atas, tingkat prosentase variabel $\mathrm{X}$ yang berhasil dicapai adalah sebesar 92\%. Jika dilihat pada tabel indeks konfirmasi nilai angket, maka nilai tersebut berada pada interval $81 \%$ sampai dengan $100 \%$ dengan kategori sangat kuat. Hal ini menunjukkan bahwa penerapan kinerja guru MTs Negeri 4 Banyuwangi tergolong sangat baik.

3. Pengaruh Sarana dan Prasarana Pendidikan (X) Terhadap Kinerja Guru (Y)

Permasalahan yang ketiga yang ingin dijawab dalam penelitian ini adalah pengaruh sarana dan prasarana (X) terhadap kinerja guru (Y). Berdasarkan hasil uji f diperoleh hasil bahwa f hitung yaitu 27,220 dibandingkan dengan $\mathrm{f}$ tabel dengan $\mathrm{N}=45$ taraf signifikansi 5\%=1,66 dan taraf signifikansi $1 \%=2,06$ menghasilkan hasil uji $\mathrm{f}>$ dari $\mathrm{f}$ tabel maka $\mathrm{Ha}$ diterima Dengan demikian hasil penelitian ini juga menunjukkan bahwa adanya pengaruh penerapan sarana dan prasarana terhadap kinerja guru MTs Negeri 4 Banyuwangi.

4. Besar Pengaruh Sarana dan Prasarana Pendidikan (X) Terhadap Kinerja Guru (Y)

Permasalahan keempat yang ingin dijawab dalam penelitian ini adalah seberapa besar pengaruh variabel sarana dan prasarana $(\mathrm{X})$ terhadap kinerja guru (Y). Hasil penelitian menunjukkan bahwa pengaruh penerapan sarana dan prasarana mempunyai pengaruh terhadap kinerja guru sebesar $38,8 \%$ yang dibulatkan menjadi $39 \%$, sisanya $61 \%$ dipengaruhi oleh variabel lain.

\section{F. Kesimpulan}

1. Berdasarkan hasil angket variabel $X$ sarana dan prasarana pendidikan di MTs Negeri 4 Banyuwangi Sumberayu Muncar Banyuwangi diperoleh hasil hitung sebesar $93 \%$ yang termasuk kategori sangat baik.

2. Berdasarkan hasil angket variabel kinerja guru (Y) di MTs Negeri 4 Banyuwangi Sumberayu Muncar banyuwangi memperoleh hasil sebesar $92 \%$ tergolong sangat baik. 
3. Berdasarkan hasul uji f diperoleh hasil bahwa f hitung yaitu 27,220 dibandingkan dengan $\mathrm{t}$ tabel dengan $\mathrm{N}=45$ dengan taraf signifikansi $5 \%=$ 1,66 dan taraf signifikansi $1 \%=2,06$, menghasilkan hasil uji f $>$ dari f tabel maka Ha diterima. Dengan demikian hasil penelitian ini juga menunjukkan bahwa adanya pengaruh sarana dan prasarana pendidikan terhadap kinerja guru di MTs Negeri 4 Banyuwangi.

4. Berdasarkan perhitungan yang dilakukan dengan menggunakan rumus regresi linier sederhana, $\mathrm{t}$ hitung diperoleh 5,217 dengan taraf siginifikansi $0,000<0,05$ yang berarti diperoleh pengaruh yang signifikan dengan koefisien regresi sebesar 0,388 yang dipersenkan menjadi 38,8\%. Dengan demikian besarnya pengaruh antara sarana dan prasarana pendidikan terhadap kinerja guru adalah sebesar 38,8\% sedangkan $61,2 \%$ dipengaruhi oleh faktor lain.

\section{G. Daftar Pustaka}

Barnawi \& Arifin (2016). Manajemen sarana dan prasarana sekolah. Jogjakarta: AR Ruzz Media

Farikhah, Siti. 2015. Manajemen Lembaga Pendidikan. Yogyakarta. Aswaja Pessindo

Irawan, Irjus. 2015. Pengantar sarana dan prasarana pendidikan. Yogyakarta. CV Budi Utama

Karwati \& Priansa. 2015. Manajemen Kelas, Guru Profesional Yang Inspiratif, Kreatif, Menyenangkan, Dan Berprestasi. Bandung. CV ALFABETA

Mangkunegara, Anwar Prabu. 2009. Manajemen Sumber Daya Manusia Perusahaan. Bandung. PT Remaja Rosdakarya

Matin \& Fuad, Nurhatati ( 2017).manajemen sarana dan prasarana konsep dan aplikasinya. Jakarta. PT Rajagrafindo Persada

Muhid, Abdul. 2012. Analisi Statistika 5 Langkah Praktis Analisis Statistic Dengan SPSS For Windows. Sidoarjo. Zifatama Publishing

Mulyasa. 2011. Menjadi Guru Professional Menciptakan Pembelajaran Kreatif Dan Menyenangkan. Bandung. PT Rajagrafindo Persada

Mulyasa. 2014. Manajemen Berbasis Sekolah Konsep Strategi Dan Implementasi. Bandung. PT Remaja Rosdakarya

Pengaruh Sarana Dan Prasarana Pendidikan Terhadap Kinerja Guru MTS

Negeri 4 Banyuwangi

Nur Hidayati, Ufik Dzuroidah 
Pianda, Didi. 2018. Kinerja Guru, Kompetensi Guru, Motifasi Kerja, Kepemimpinan Kepala Sekolah. Sukabumi. CV Jejak Publizher

Saefudin, Udin. 2013. Pengembangan Profesi Guru. Bandung. CV ALFABETA

Sagala, Udin. 2013. Manajemen Strategi Dalam Peningkatan Mutu Pendidikan. Bandung. CV ALVABETA

Yamin \& Maisah. 2009. Manajemen Pembelajaran Kelas Strategi Meningkatkan Mutu Pembelajaran. Jakarta. Gaung Persada Press 